ISSN 1112-9867

Available online at http://www.jfas.info

\title{
THERMAL, ELECTROCHEMICAL AND MECHANICAL PROPERTIES OF SHAPE MEMORY ALLOY DEVELOPED BY A CONVENTIONAL PROCESSING ROUTE
}

\author{
T. Ahmad ${ }^{1 *}$, A. N. Malik ${ }^{1}$, S. S. Raza ${ }^{1}$, M. Kamran ${ }^{1}$, M. U. Manzoor ${ }^{1}$, A. Salman ${ }^{1}$, F. Hussain ${ }^{1}$, \\ F. Riaz ${ }^{1}$, R. Ahmad ${ }^{1}$, M. N. Akhtar ${ }^{2}$
}

${ }^{1}$ Department of Metallurgy and Materials Engineering CEET, University of the Punjab, Lahore, Pakistan

${ }^{2}$ Department of Physics, COMSATS Institute of Information Technology, Lahore, Pakistan Received: 17 October 2016 / Accepted: 15 April 2017 / Published online: 1 May 2017

\begin{abstract}
$\mathrm{A} \mathrm{Cu}$ based shape memory alloy (Cu-Al-Ni) having a composition $83 \% \mathrm{Cu}, 14 \% \mathrm{Al}, 3 \% \mathrm{Ni}$, was developed and studied to determine the shape memory effect. Powder of $\mathrm{Cu}, \mathrm{Al}$ and $\mathrm{Ni}$ was melted in a pit furnace at about $1550^{\circ} \mathrm{C}$, and casted alloy was heat treated at $850^{\circ} \mathrm{C}$ for a period of 50 minutes followed by water quenching. Microstructure characterization of alloy ( $\mathrm{Cu}-\mathrm{Al}-\mathrm{Ni})$ was carried out to determine the pre-quenched (cast structure) and quenched martensitic structure. The microstructure analysis of developed samples showed needle like structure of quenched martensite after heat treatment. It has a very good resemblance with structure of casted shape memory alloy obtained from the vacuum induction process. The Vickers hardness test was also performed. Quenched microstructure with improved hardness than pre-quenched structure was observed.
\end{abstract}

Keywords: Shape Memory Alloy, Microstructure, Mechanical Properties.

Author Correspondence, e-mail: tahirengg4051@yahoo.com

doi: http://dx.doi.org/10.4314/jfas.v9i2.15

Journal of Fundamental and Applied Sciences is licensed under a Creative Commons Attribution-NonCommercial 4.0 International License. Libraries Resource Directory. We are listed under Research Associations category. 


\section{INTRODUCTION}

The term Shape Memory Alloys (SMA) are put in application to a specific class of metallic materials that manifest the ability to return to a formerly defined size or shape when put into a suitable thermal methodology. Usually, these type of materials may be plastically deshaped at a relatively small temperature and upon exposure to some specific elevated temperature will come back to their shape attained before the deformation [1]. A lot of research has been carried out on shape memory alloys recently. Among them, Wongweerayoot et al. [2] prepared a NiTi-Cu shape memory alloy bimorph actuator and studied the effect of annealing conditions on nitinol (NiTi) at various temperatures i.e., 500,600 , and $650^{\circ} \mathrm{C}$ for $30 \mathrm{~min}$. The annealing temperatures of 600 and $650^{\circ} \mathrm{C}$ produced appropriate crystalline structure of NiTi. The actuator prepared at annealing temperature of $650^{\circ} \mathrm{C}$ for $30 \mathrm{~min}$ with two pre-stressing conditions of straight and curved mold. It showed that deflection of the actuator is more affected by annealing temperature. Todorovic et al. [3] used melt spinning technique to produce thin $\mathrm{Cu}-\mathrm{Al}-\mathrm{Ni}$ ribbons. The results showed that $\mathrm{Cu}-\mathrm{Al}-\mathrm{Ni}$ base alloys almost completely reduced metabolic activity of peripheral blood mononuclear cells (PBC) during MTT (3-(4, 5-Dimethylthiazol-2-Yl)-2, 5Diphenyltetrazolium Bromide) test while none of $\mathrm{Cu}-\mathrm{Al}-\mathrm{Ni}$ ribbon types showed a statistically significant effect on the metabolic activity of cells. Alana et al. [4] prepared different solutions for evaluation of TiNi polished surfaces and noticed their electrochemical behavior: Ringer solution, Hanks' balanced salt (HBSS) solution, Hanks solution and in Saline body fluid solution. All simulated body fluids revealed almost the same corrosion phenomenon. It was also found that Ringer solution proved itself to be most corrosive followed by SBF and HBSS. The corrosion potential also changes in a similar fashion. Francois et al. [5] had prepared SMA wire of nitinol mesh into technical fabric for examining it weaving properties as compared to stainless steel wire. These fabrics were investigated to use inside composites structure. It was found that nitinol wire showed better properties of weaving as compared to stainless steel. Ming et al. [6] discussed the industrial applications of shape memory alloys like eye glass having frames for super-elasticity and super elastic wire of cellular phone antennas. He also discussed the uses of superelastic NiTi powder for the resistance of SnPdAg solder against failure due to thermal stresses. European has been recently using NiTiNb plug for sealing high-pressure fuel passages in diesel engine injectors made of SMA actuators. This research is aimed to develop shape 
memory alloy $(\mathrm{Cu}-\mathrm{Al}-\mathrm{Ni})$ produced by a conventional processing route and study its mechanical properties and electrochemical behavior.

\section{EXPERIMENTAL WORK}

High purity of about $99.99 \% \mathrm{Cu}-\mathrm{Al}-\mathrm{Ni}$ powder was purchased from local market. In this research the wt. \% ratio of $\mathrm{Cu} 83 \%, \mathrm{Al} 14 \%$, and $\mathrm{Ni} 3 \%$ was taken and mixed using a ball mill for one hour. The melting of $\mathrm{Cu}, \mathrm{Al}$ and $\mathrm{Ni}$ alloy was done in Pit furnace. Metal powder of $\mathrm{Cu}, \mathrm{Al}$ and $\mathrm{Ni}(150 \mathrm{~g}$ calculated composition) was put in graphite crucible and placed in pit furnace. The furnace was operated at $1550^{\circ} \mathrm{C}$ for 1 hour. The molten alloy was poured into Graphite Mold to get a rectangular shape test specimen. The cast specimen of the alloy in the rectangular form was cut into difference samples with the help of electric hacksaw for hardness, SEM, DSC and electrochemical behavior studies. Phase transformation temperature was determined by DSC at a cooling rate of $20^{\circ} \mathrm{C} / \mathrm{min}$ by using an inert atmosphere.

Micro-Hardness-Tester was used to determine the hardness of the cast alloy. The cast samples mounted and ground with the help of emery papers of different sizes $(60,120$ and 180 up to 1000). The cast alloy samples were also polished and etched with etching solution of Ammonium hydroxide $\left(\mathrm{NH}_{3} \mathrm{OH}\right) 5$ parts, Hydrogen per Oxide $\left(\mathrm{H}_{2} \mathrm{O}_{2}\right)$ 2-3 parts, Water $\mathrm{H}_{2} \mathrm{O} 5$ parts. Casted alloy was also heat treated (homogenized) at $850^{\circ} \mathrm{C}$ for a period of 50 minutes followed by water quenching. Lieca Light Optical Microscope and SEM were used for microstructure analysis of developed shape memory alloy.

\section{RESULTS AND DISCUSSION}

\subsection{DSC Analysis}

The DSC analysis of as cast and quenced samples of $\mathrm{Cu}-14 \% \mathrm{Al}-3 \% \mathrm{Ni}$ shape memory alloy is shown in fig. 1 . The cooling rate has been set $20^{\circ} \mathrm{C} / \mathrm{min}$ for all samples. All samples were tested in an inert atmosphere. The obtained curve is shown in Fig.1. 


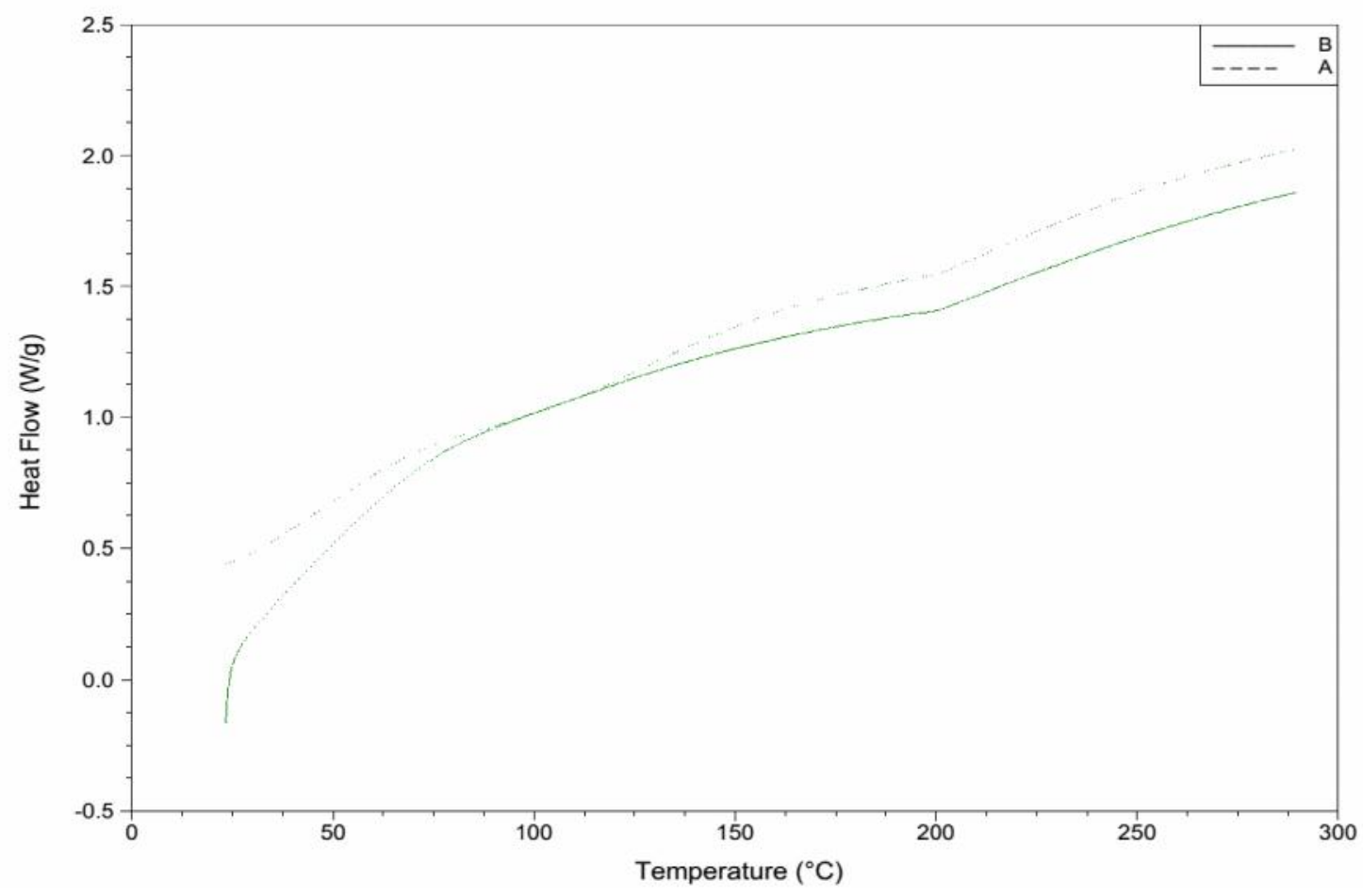

Fig.1. DSC scan of samples A (Cast Sample) \& B (Quenched Sample)

Transformation temperatures of cast and quenched samples are inserted in Table 1.

Table1. Transformation temperatures of cast and quenched samples

\begin{tabular}{|c|c|c|c|c|c|c|}
\hline Alloys & $\mathrm{A}_{\mathrm{s}} /{ }^{\circ} \mathrm{C}$ & $\mathrm{A}_{\mathrm{p}} /{ }^{\circ} \mathrm{C}$ & $\mathrm{A}_{\mathrm{f}} /{ }^{\circ} \mathrm{C}$ & $\mathrm{M}_{\mathrm{s}} /{ }^{\circ} \mathrm{C}$ & $\mathrm{M}_{\mathrm{p}} /{ }^{\circ} \mathrm{C}$ & $\mathrm{M}_{\mathrm{f}} /{ }^{\circ} \mathrm{C}$ \\
\hline As Cast & 225 & 210 & 198 & 190 & 175 & 112 \\
\hline Quenched & 215 & 208 & 205 & 202 & 138 & 90 \\
\hline
\end{tabular}

The values of the transformation temperatures of $\mathrm{Cu}-\mathrm{Al}$ - Ni shape memory alloy lies b/w 90 and $225^{\circ} \mathrm{C}$ which is in a close resemblance with the literature values [9-12]. The slight variation in the transformation temperatures is due to difference in alloying and operating conditions. It is quite obvious from the values that the transformation temperatures show a variation in as cast and quenched structure. The trend of transformation temperatures in the structures is As $>A_{p}>A_{f}>M_{s}>M_{p}>M_{f}$. The temperature scheme validates the transformation phenomenon that 
it is in a right order. The values of heat flow from both the alloys start increasing as Martensitic transformation starts and get normalized as it finished. It gives an idea that during Martensitic transformation both alloys have dejected more heat from them and formation of needles of Martensite took place.

\subsection{Optical Microstructural Analysis}

The microstructures of as cast samples are shown in Fig 2(a,b) and quenched closely martensite are shown in Fig 3 (a,b). The micrographs are shown at different magnification clearly showed the precipitate formation in Fig 2(a,b) and parallel martensite needles are shown in Figure 3 (a, b) due to quenching of the samples.
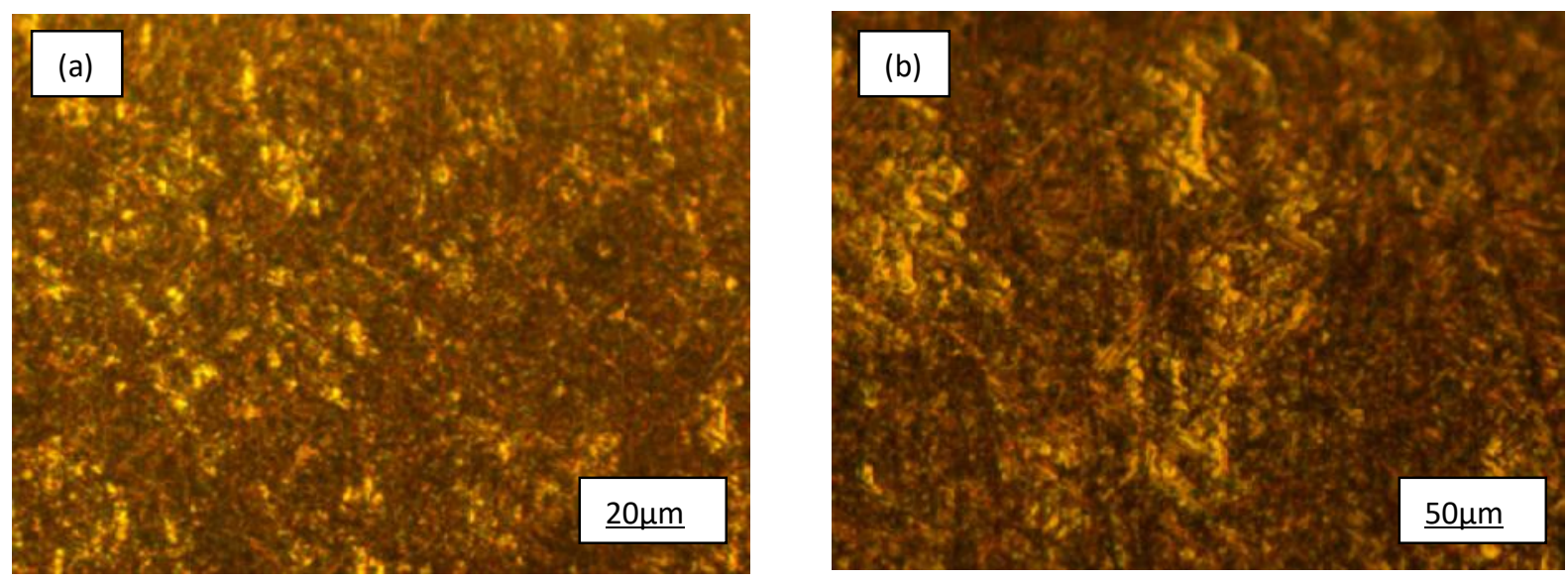

Fig2. (a, b) Optical micrographs of cast samples of Cu-Al-Ni shape memory alloy.
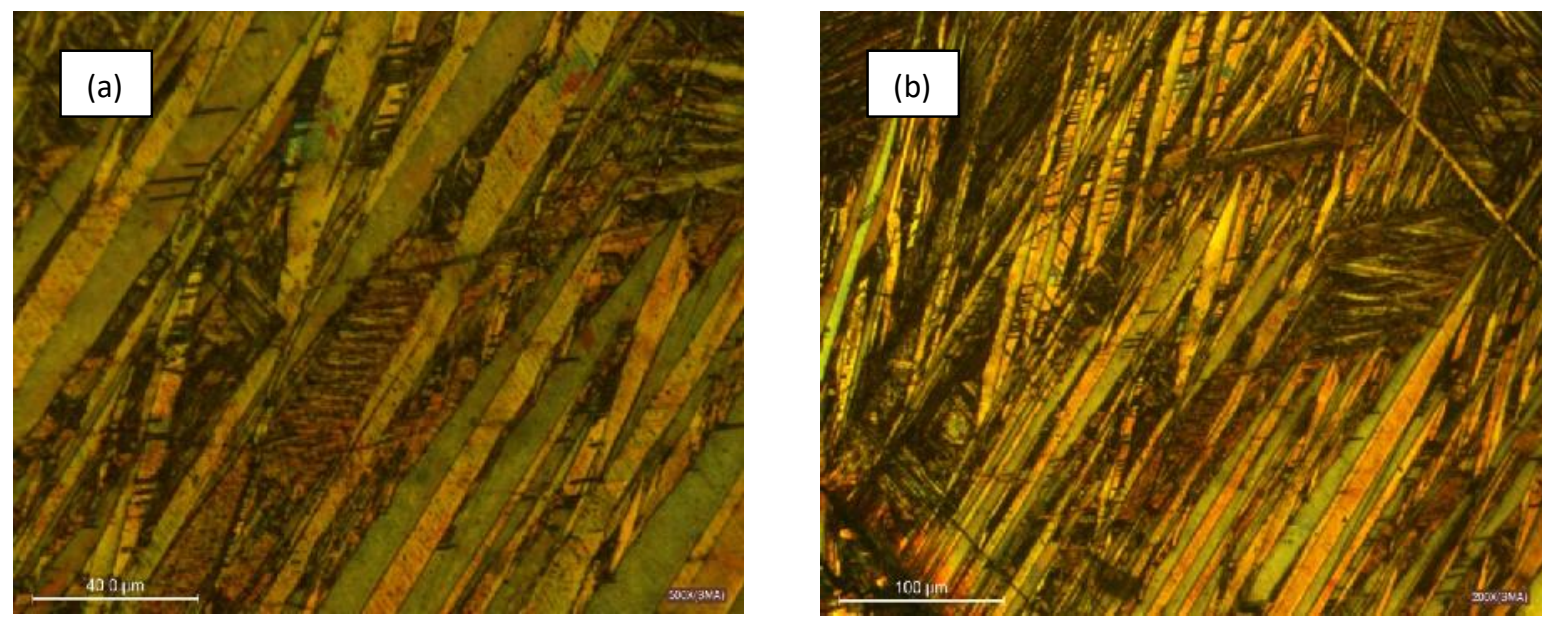

Fig.3. (a, b) Needle like structure showing the formation of martensite in shape memory alloy. 
Optical micrographs of cast and heat treated alloys are shown in Figs. 2 \&3. In the Fig. 2(a, b), microstructures of cast shape memory alloy at two dissimilar magnifications are shown. In Fig. 2a, fine grain microstructure can be distinctly seen. While in Fig. 2 b, the structure becomes much clear as the magnification increases. Dark and light grains shown in Fig. 3 a and b reveal martensite lamellar structure. Sharp needles of martensite can be clearly seen in Fig 3(b) as against in Fig 3 (a). Both microstructures give a proof of presence of some unseen needles or the ones which do not have a proper time for formation of martensitic structure. These may be due to the effect of slow cooling in that specific area or simply speaking a nonuniform cooling throughout the structure.

\subsection{Electrochemical Analysis}

Potentiodynamic polarization and open circuit potential (OCP) have been measured in a conventional three electrode electrochemical cell. A $0.9 \% \mathrm{NaCl}$ solution was prepared for analysis. The sample size was $1 \mathrm{~cm}^{2}$. For OCP total scan time was 1000 seconds and sample period was 0.5 .

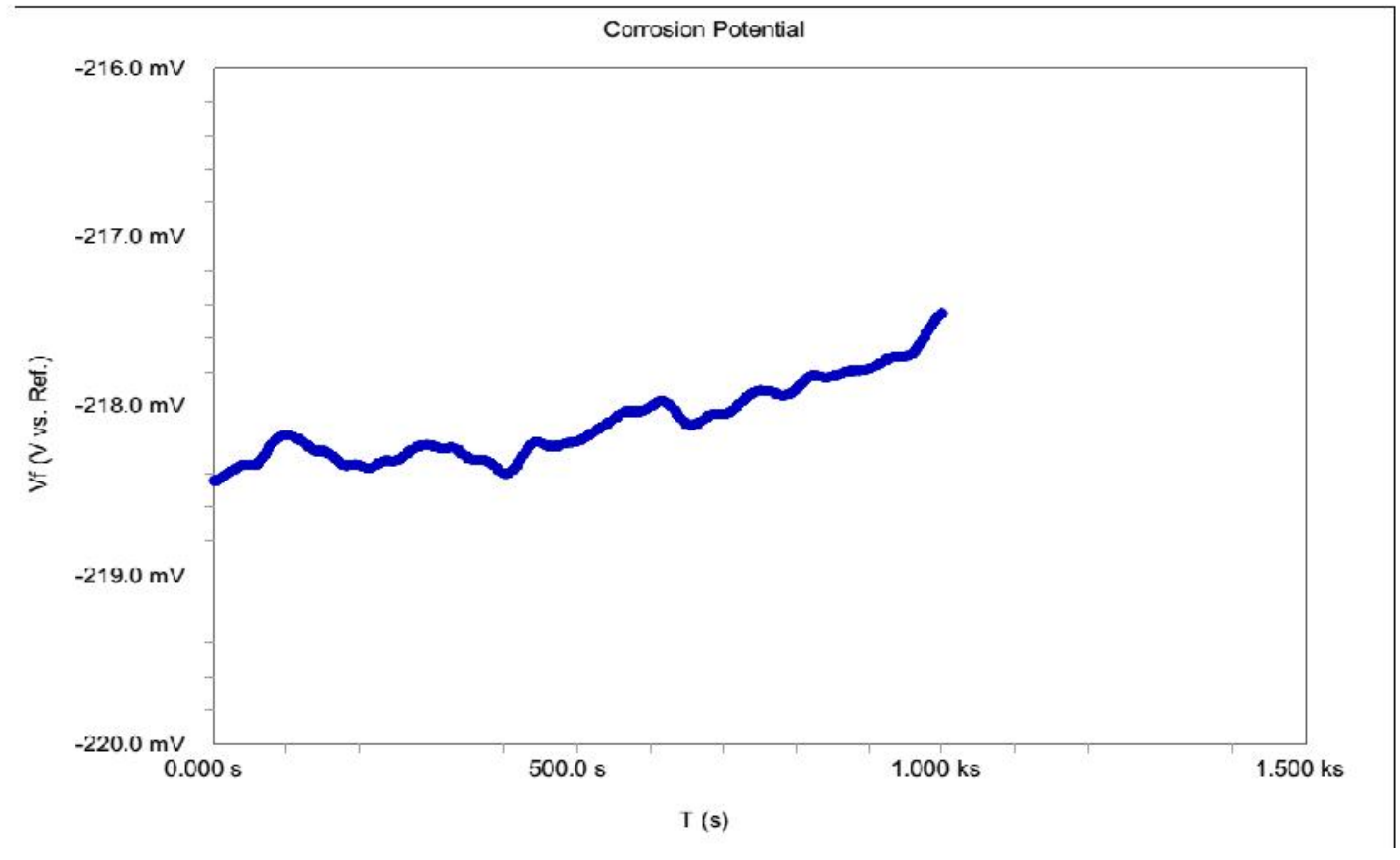

Fig.4. Measurement of OCP in $0.9 \% \mathrm{NaCl}$ Solution 
The maximum OCP value measured at $1000 \mathrm{sec}$ was $-217.5 \mathrm{mV}$ which is the most active potential. This potential is achieved at a value of $1000 \mathrm{sec}$. Note that the curve shows an increasing trend but not in a smooth fashion, this might be due to contamination in the solution.

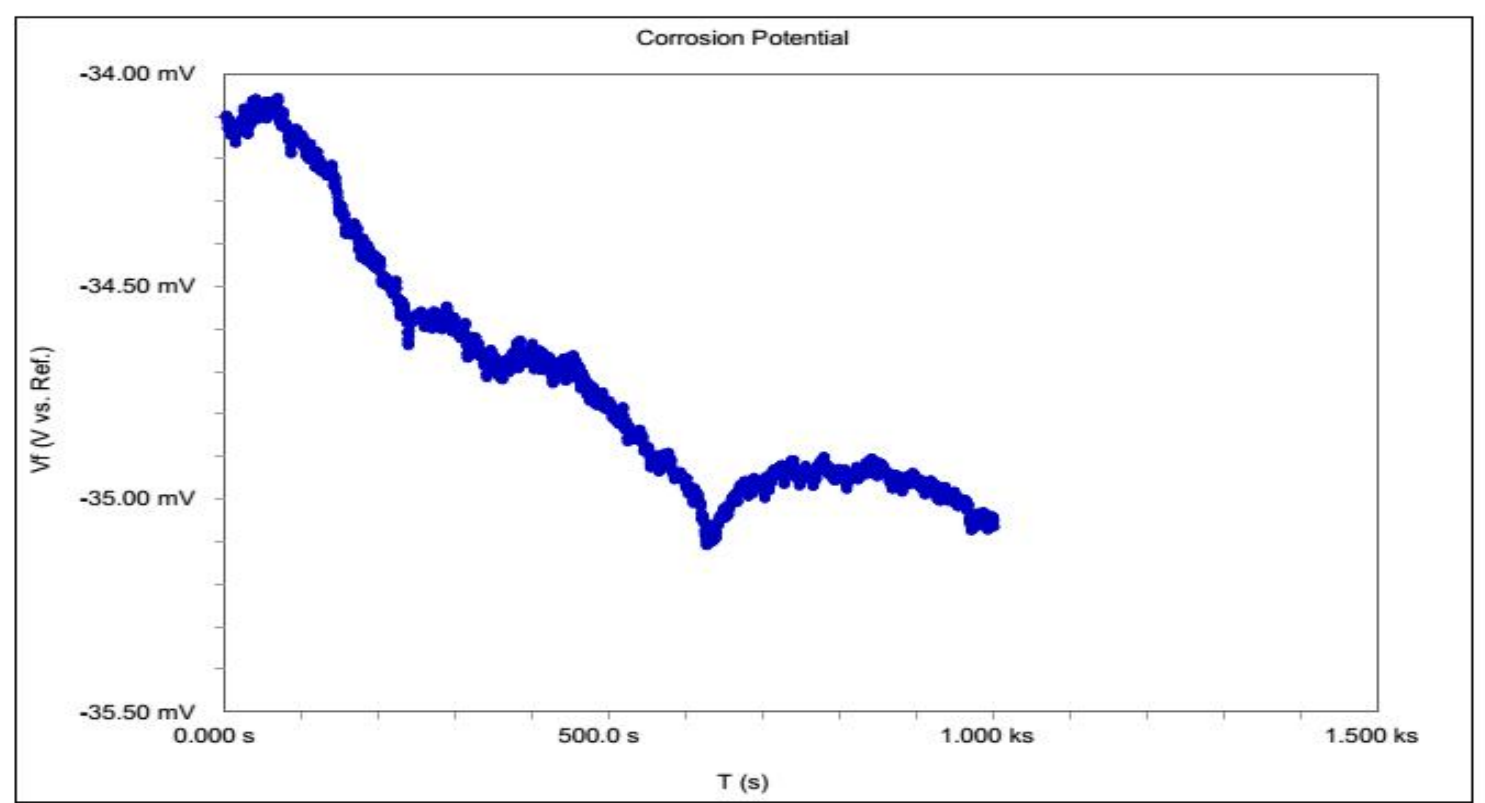

Fig.5. Measurement of OCP of Cu-14\% Al- 3\% Ni Shape Memory Alloy in Dextrose Solution

The maximum OCP value was noticed at $-34.125 \mathrm{mV}$ at an initial stage of the scan and it decreases gradually with time as shown in fig.5. This test has been performed in a dextrose solution with a sample period 0.5 . The sample dimensions are $1 \mathrm{~cm} * 1 \mathrm{~cm}$. The corrosion potential for dextrose solution is higher for shape memory alloy as compared to brine solution. 


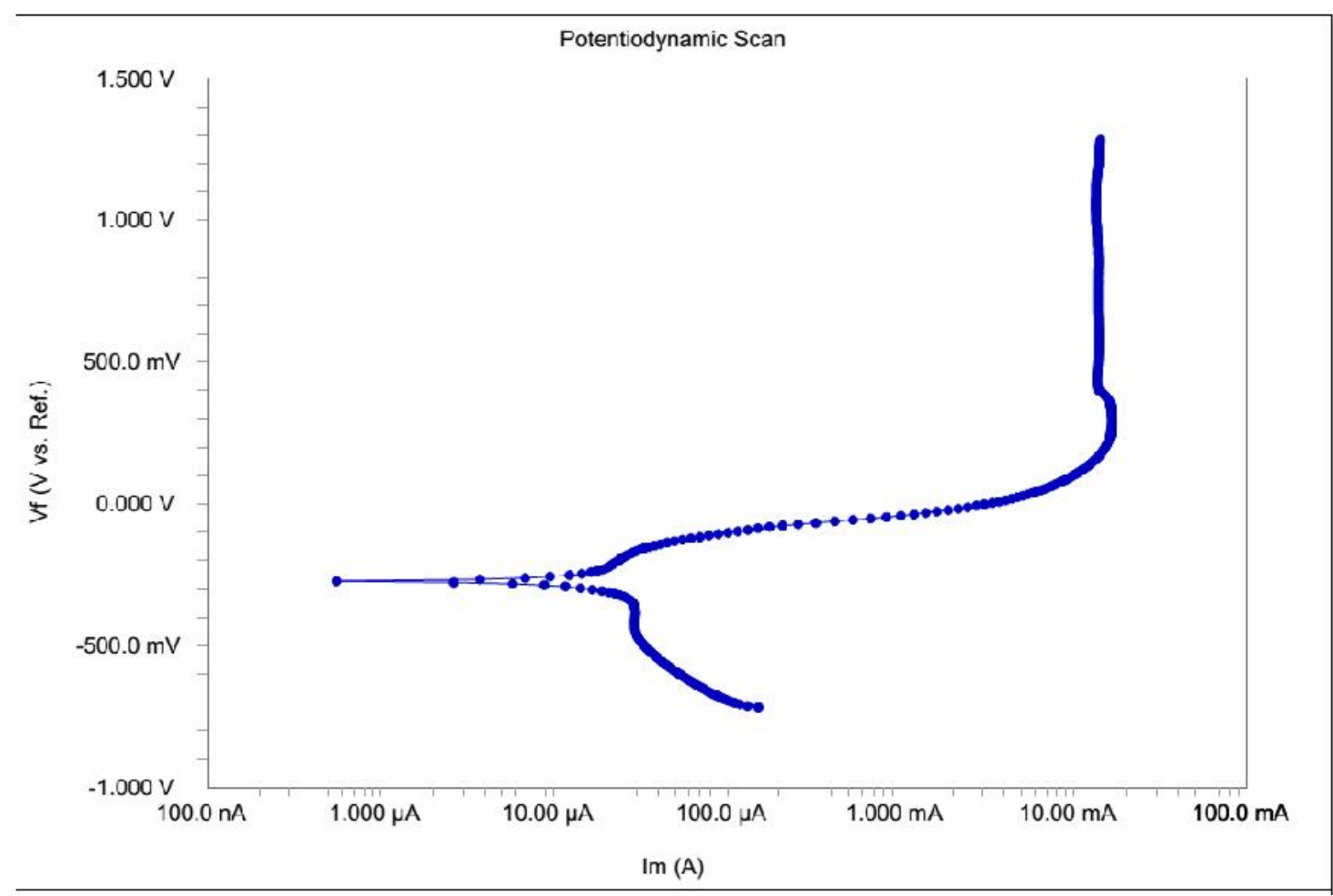

Fig.6. Potentiodynamic polarization curve in $0.9 \% \mathrm{NaCl}$ solution

Fig. 6 shows a potentiodynamic polarization behavior of shape memory alloy in a brine solution. The lower part shows a cathodic polarization upto $-250 \mathrm{mV}$ and then there is an activation region $\mathrm{b} / \mathrm{w} 10 \mu \mathrm{A}$ and $10 \mathrm{~mA}$. After it passivation starts due to formation of a passive film of $\mathrm{CuCl}_{2}$. The activation region shows the dissociation of $\mathrm{Cu}$ into $\mathrm{Cu}^{+2}$ ions and after it there is a formation of $\mathrm{CuCl}_{2}$ passive layer which further inhibits the corrosion of $\mathrm{Cu}$. Brine solution provides $\mathrm{Cl}^{-1}$ ions for the formation of $\mathrm{CuCl}_{2}$. 


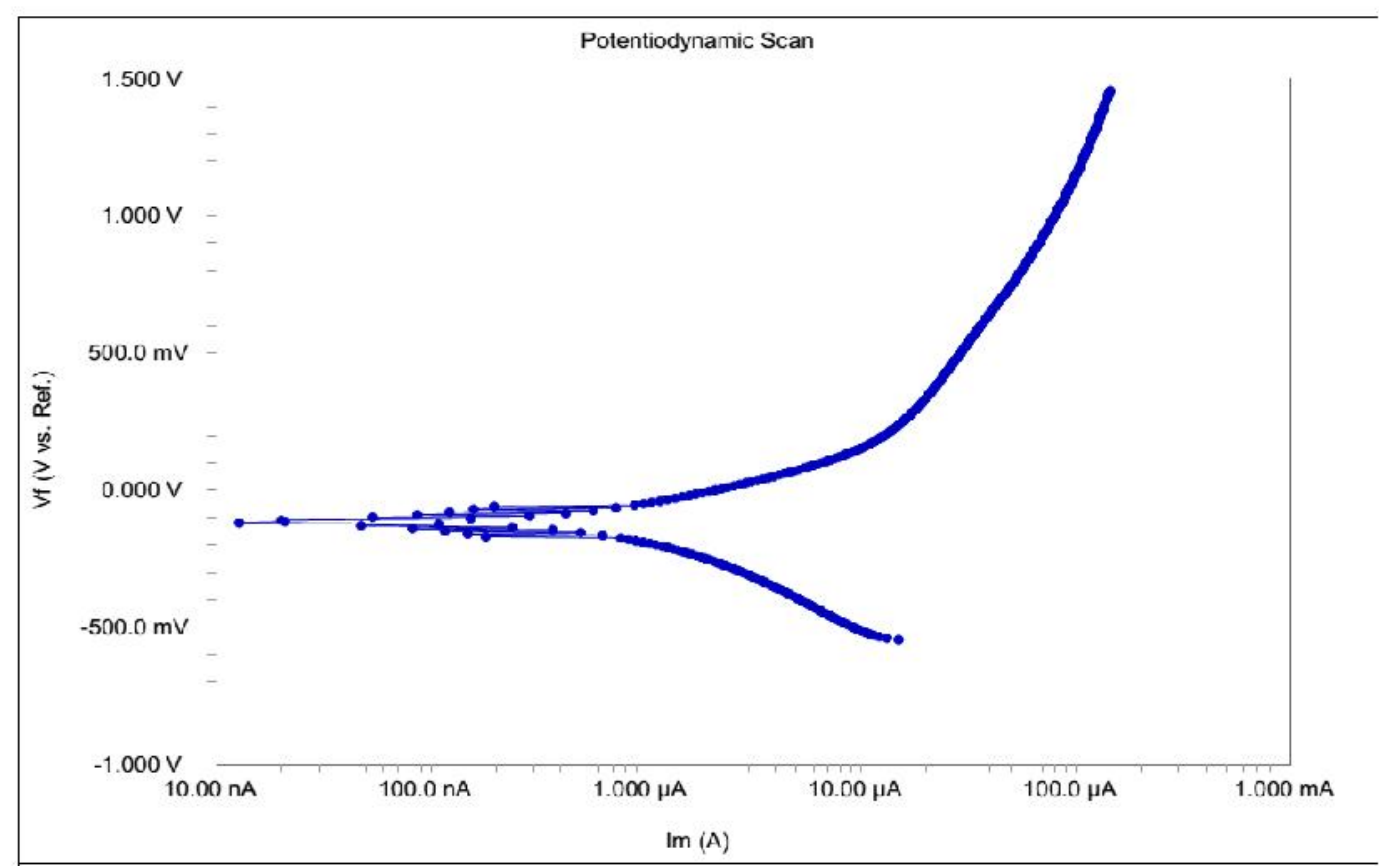

Fig.7. Potentiodynamic polarization curve in Dextrose Solution

Potentiodynamic polarization curve for shape memory alloy in Dextrose solution has been shown in Fig 7. The alloy reveals a less activation region in this solution as compared to brine solution. It means that there is a low number of $\mathrm{Cl}^{-1}$ ions formations as compared to brine solution. The chances of corrosion of alloy in dextrose solution are less as compared to brine solution.

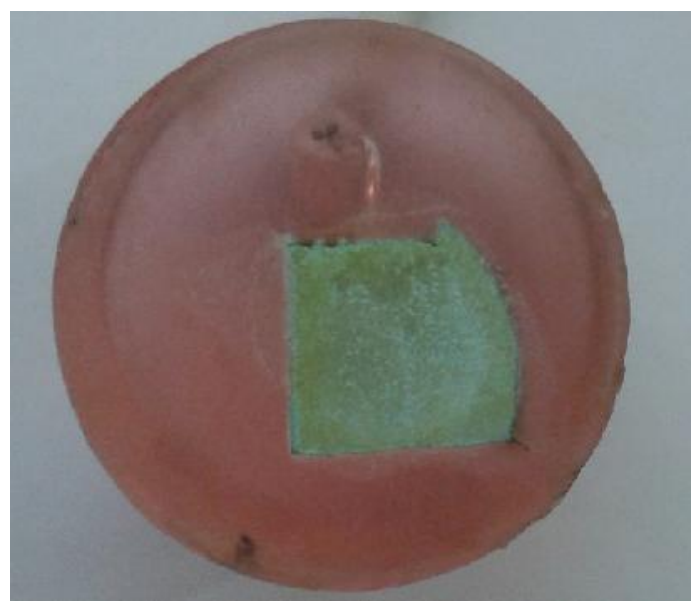

Fig.8. Formation of greenish colour of $\mathrm{CuCl}_{2}$ on the sample 
The greenish color of $\mathrm{CuCl}_{2}$ in fig8. further confirms the formation of $\mathrm{CuCl}_{2}$ in the passive region which prevents the sample from further corrosion. The formation of $\mathrm{CuCl}_{2}$ is due to the presence of $\mathrm{Cl}^{-1}$ ions in the brine solution.

\subsection{SEM and EDX Analysis}

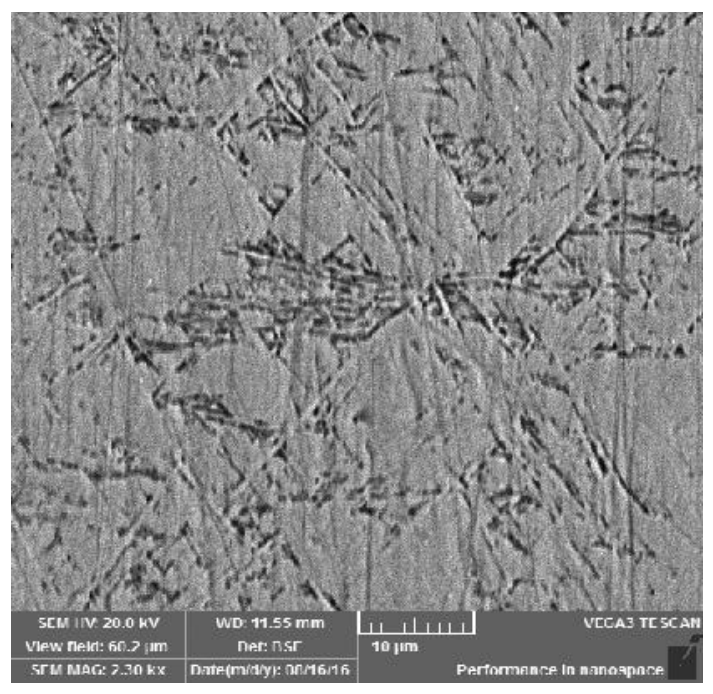

Fig.9. SEM image of as quenched sample of shape memory alloy.

Coarse martensite plates of shape memory alloy were observed when sample was heat treated at $850^{\circ} \mathrm{C}$ for period of 50 mints followed by water quenching. Note that martensite lamellae are not found everywhere which represents a non uniform quenching. However the presence of plates reveals a quenched structure as revealed in fig.9.
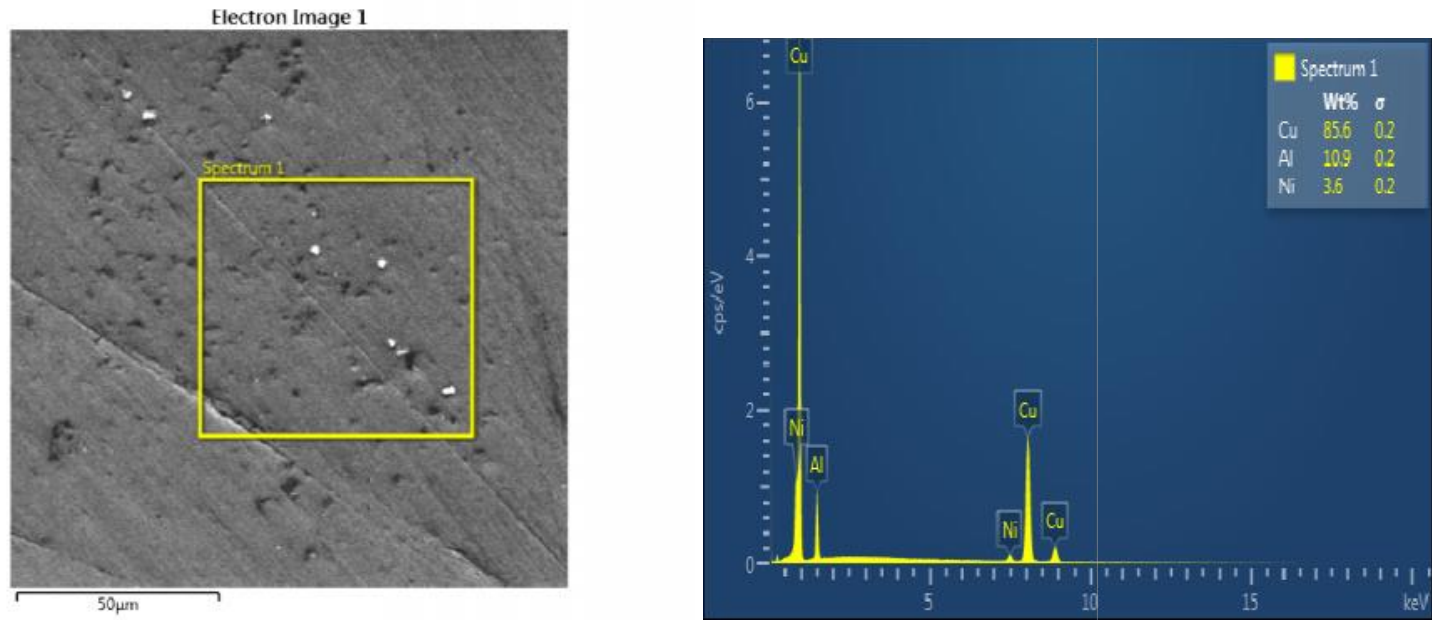

Fig.10. EDX analysis of as cast sample of shape memory alloy. 
EDX analysis further confirms the purity of alloy with a slight variation in composition from the parent alloy as shown in fig.10. This variation may be due to segregation or due to some oxidation of $\mathrm{Al}$, as $\mathrm{Al}$ lose its weight as revealed by the analysis.
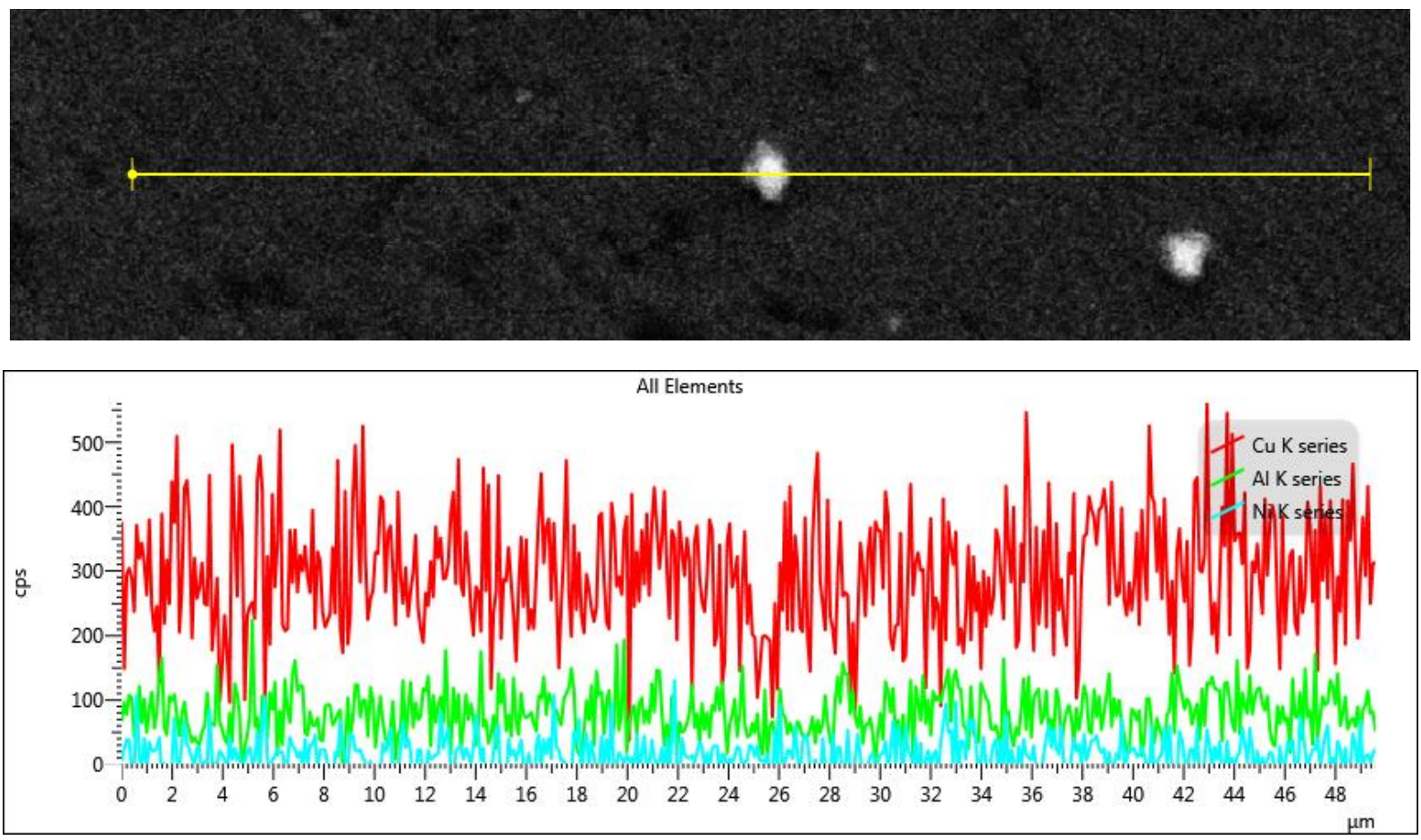

Fig.11. Horizontal scan representing the compositional analysis

Since the base metal is $\mathrm{Cu}$ and it is in higher amount as compared to $\mathrm{Al}$ and $\mathrm{Ni}$ the horizontal SEM scan further verifies the results. The red colour line scan confirms the presence of higher amount of $\mathrm{Cu}$ while $\mathrm{Al}$ and $\mathrm{Ni}$ in lower amounts sequentially across the sample. The ups and downs in the scan show segregation.

Table 2. Vickers microhardness test readings of alloys

\begin{tabular}{|c|c|c|c|c|}
\hline Samples Detail & 1 & 2 & 3 & Average value \\
\hline As Cast & $336 \mathrm{Hv}$ & $347 \mathrm{Hv}$ & $335 \mathrm{Hv}$ & $339 \mathrm{Hv}$ \\
\hline Quenched & $370 \mathrm{Hv}$ & $374 \mathrm{Hv}$ & $369 \mathrm{Hv}$ & $371 \mathrm{Hv}$ \\
\hline
\end{tabular}


Three successive Vickers hardness readings were noted from cast and quenched alloys and an average value was calculated from them. Both alloys show a different value at each measurement as the readings are from the surface. It is quite obvious that the microhardness values increases with quenching. The variations in the hardness values and SEM horizontal scan give an idea about structure and composition dissimilarity throughout the structure. Aydog $\breve{d u}$ presented the hardness value $281 \mathrm{Hv}$ of $\mathrm{Cu}-\mathrm{Al}-\mathrm{Ni}$ alloy when heat treatment has been done at $930^{\circ} \mathrm{C}$ for ashomogenized sample and for quenched sample he put up a value of $321 \mathrm{Hv}$ [7]. Gojic et al. [8] put up a value of $275 \mathrm{Hv}$ for shape memory alloy $\mathrm{Cu}-13.16 \%$ Al-4.11\%Ni. Shokuhfar and Rezvani made two different compositions of alloys and they put up $220 \mathrm{Hv}$ as a hardness values of their alloys.

\section{CONCLUSIONS}

After the analysis of shape memory alloy produced by pit furnace techniques following results are generated:

1. DSC experiment showed that there is no significant difference in transformation temperatures when compared the results with the literature values.

2. Optical microscopy results confirmed the formation of martensitic lamellae with a fine and coarse morphology with some unfinished lamellae in between the structure.

3. OCP and potentiodynamic curves show the activation, passivation and cathodic polarization regions which mention the corrosion properties of shape memory alloy.

4. The chances of corrosion of alloy are less in dextrose solution as compared to brine solution.

5. SEM/EDX analysis confirms the composition of alloy with a slight variation and revealed a segregated structure.

6. Hardness values are higher for quenched sample as compared to as cast sample and values for both the samples are higher when compared them with the literature values.

\section{ACKNOWLEDGEMENTS}

The authors are thankful for the financial support of The University of the Punjab, Lahore, Pakistan. 


\section{REFERENCES}

1. Otsuka, Kazuhiro, and Clarence Marvin Wayman. Shape memory materials. Cambridge university press, 1999.

2. Wongweerayoot, E., W. Srituravanich, and A. Pimpin. "Fabrication and Characterization of Nitinol-Copper Shape Memory Alloy Bimorph Actuators." Journal of Materials Engineering and Performance 24.2 (2015): 635-643.

3. Todorović, Ana, et al. "BIOCOMPATIBILITY EVALUATION OF Cu-Al-Ni SHAPE MEMORY ALLOYS." CONTEMPORARY MATERIALS 2.5 (2014): 228-238.

4. Alana Witt Hansen, Luciane Taís Führ, Leonardo Marasca Antonini, Denis Jardim Villarinho, Cláudia Eliana Bruno Marino, Célia de Fraga Malfatti, The Electrochemical Behavior of the NiTi Alloy in Different Simulated Body Fluids, Materials Research. 2015; 18(1): 184-190.

5. Francios Boussu, Guillaume Bailleul, Jean-Luc Petitniot, Hugues Vinchon, Development of Shape Memory alloy fabrics for Composites Structures, AUTEX Research Journal, Vol. 2 (1) 2002, 1-7.

6. Wu, Ming H., and L. M. Schetky. "Industrial applications for shape memory alloys." Proceedings of the international conference on shape memory and superelastic technologies. 2000.

7. Aydogdu A, Aydogdu Y, Adigüzel O. Improvement of hardness and microstructures by ageing in shape memory CuAlNi alloys. Le Journal de Physique IV. 1997 Nov 1; 7(C5):C5-311. 8. Rezvani MR, Shokuhfar A. The effect of chemical composition on crystal size and mechanical properties of nanostructured $\mathrm{Cu}-\mathrm{Al}-\mathrm{Mn}$ shape memory alloy prepared by mechanical alloying tecnique. In: Proceeding of 4th International conference on nanostructure (ICNS4); 2012:15251527.

9. Recarte V, Perez-Landazabal JI, Ibarra A, No ML, Juan JS. High temperature b phase decomposition process in a $\mathrm{Cu}-\mathrm{Al}-\mathrm{Ni}$ shape memory alloy. Mater Sci Eng A. 2004; 378:2-238.

10. Zengin R, Ceylan M. Influence of neutron urradiation on the characteristic of $\mathrm{Cu}-13 \% \mathrm{wt}$. Al-4\% wt. Ni shape memory alloy. Mat Lett. 2003; 58:55-9.

11. Suresh N, Ramamurty U. Aging response and its effect on the functional properties of $\mathrm{Cu}-$ Al-Ni shape memory alloys. J Alloy Compd. 2008; 449:113-8. 
12. Bouabdallah M, Baguenane-Benalia G, Saadi A, Cheniti H, Gachon JC, Patoor E. Precipitation sequence during ageing in b1 phase of $\mathrm{Cu}-\mathrm{Al}-\mathrm{Ni}$ shape memory alloy. $\mathrm{J}$ Therm Anal Calorim. 2013; 112:279-83.

\section{How to cite this article:}

Ahmad T, Malik A N, Raza S S, Kamran M, Manzoor M U, Salman A, Hussain F, Riaz F, Ahmad R,Akhtar M N, Thermal, electrochemical and mechanical properties of shape memory alloy developed by a conventional processing route. J. Fundam. Appl. Sci., 2017, 9(2), 847-860. 